\title{
Another year of armaments
}

THE annual appearance of World Armaments and Disarmament from SIPRI, the Stockholm International Peace Research Institute, has in recent years drawn a mixture of admiration that so much is done by such a small operation, concern at the relentless pace of armaments and the almost imperceptible motion of disarmament and, at least from us, nagging worries that there may be pressures on SIPRI, from within or without, to take a more active role in speaking up against armaments and for disarmament. This worry is not because we disagree with such objectives - it is simply that in a field where information is scarce and intelligent extrapolations necessary, preconceptions can drastically alter conclusions. This year's volume (published by Taylor \& Francis, London, at $£ 18.00$ ) carries on in the same valuable tradition, again puts those who are interested in military matters in SIPRI's debt, and again raises those nagging worries.

Last year the total world military expenditure was getting on for $\$ 400$ billion. In real terms this figure has risen $80 \%$ in the past 20 years. But this rise has been by no means uniform--since 1967 the total has grown by only $13 \%$, and at present climbs by around $1 \%$ per year. NATO and the Warsaw Treaty Organisation in fact contribute almost no growth; it largely comes from the vigour with which the Third World has acquired arms. In twenty years the Middle East has multiplied its arms expenditure twentyfold, though conceivably this grotesque expansion is now at an end. Maybe China is the next expansion area-for all the political storm concerning remarks that Britain's Chief of Defence Staff, Sir Neil Cameron, made in Peking about Britain and China's common "enemy at our door", it was his comments in Hong Kong that should have been widely quoted. For he spoke quite openly about China's need to move from low to high technology, and left no doubt that the armaments manufacturers of the West should be happy to take part in such a profitable operation.

The strategic arms limitation talks, SALT 2, first mooted in December 1974, have still not produced any final agreement, even though SALT 1 has expired. The problems seem to be mainly in how to treat cruise missiles and the Russian supersonic bomber, although recent reports suggest that enough progress has been made for a treaty to be signed this summer. But, as SIPRI points out, any treaty is unlikely to affect either side's arsenal in a quantitative way; the numbers of missiles, bombers and submarines permitted are likely to be pretty well what both sides want. This focuses attention on whether SALT 2 can have any qualitative impact, maybe by ruling out certain new types of missile. One of the disappointments of SALT has been that the talks have ended up seeming to authorise new qualitative developments that each side wanted and proposing numerical limits with which they were happy to live. Could a new round bring anything different?

SIPRI would like to see a clampdown on mobile intercontinental ballistic missiles. These have no fixed abode and so are extremely difficult to eliminate. A US version under study at present, the M-X, could come in one of two varieties. Either a missile base could contain many silos which were regularly loaded and unloaded with missiles or decoys, making it impossible to tell from satellite reconnaissance which particular silos are worth attacking. Or an underground network of tunnels perhaps thirty kilometres long and fitted with blast doors would contain missiles on trucks. If the need arose, the missile would be pushed up through the soil and fired. Attack of the base would be almost pointless as reconnaissance could not reveal the location of trucks at any particular time.

Is this new generation of mobile missiles a bad thing? Clearly it is in all sorts of ways-vertical proliferation, yet more expenditure and so on. But should it be legislated out of existence by SALT? SIPRI says that it should, as it would "not only destabilise . . . the strategic balance ... but also seriously complicate the negotiation of future strategic arms limitation agreements". In this SIPRI could be wrong. Up to the present submarines have fulfilled a similar role of an almost invulnerable force, but improvement in anti-submarine warfare techniques are slowly eroding this. There is a possibility that late in the century nations will no longer be able to count on their submarine forces for some form of ultimate reassurance. Maybe if both superpowers agreed to develop mobile ICBMs in a controlled and measured way, such a force would take over this role and conceivably stabilise rather than destabilise. 